Original Research Paper

\title{
Keanekaragaman Mollusca Sebagai Bioindikator Kualitas Perairan di Kawasan TPA Kebon Kongok Lombok Barat
}

\author{
Athifah $^{1 *}$, Maya Nuansa Putri ${ }^{1}$, Sahid Imam Wahyudi $^{1}$, Rosalina Edy ${ }^{1}, \operatorname{Immy~Suci~Rohyani~}^{1}$ \\ ${ }^{1}$ Program Studi Biologi, Fakultas Matematika dan Ilmu Pengetahuan Alam, Universitas Mataram \\ Jl. Majapahit 62 Mataram, 83125
}

Article history

Received: 4 Agustus 2018

Revised: 5 November 2018

Accepted: 11 Januari 2019

Published: 15 Februari 2019

*Corresponding Author: Athifah,

Program Studi Biologi, Fakultas Matematika dan Ilmu Pengetahuan Alam, Universitas Mataram

Email:

athifa.ifah@gmail.com
Abstract: Research has been done in the area of Kebon Kongok landfill by looking at the diversity of Mollusca as a bioindicator of water quality. This research is important because the river in Kebon Kongok landfill area is utilized by the surrounding community for daily needs. The research was conducted in May-June 2018 at Sungai Ayu River, Gerung District, West Lombok which aims to provide information about the water quality in this area. The research was done by purposive sampling method using cruising technique. There are 3 research stations selected based on the difference of environmental conditions around the waters of Kebon Kongok landfill. Station 1 is located east of the Kebon Kongok landfill adjacent to the landfill waste pond landfill, station 2 is located in the northwest part of the Kebon Kongok landfill where it is located adjacent to the main river body and station 3 is located in the southwest adjacent to the residential area. There were 13 Mollusca species belonging to 8 families: Lymnaeidae, Ampullaroidae, Thiaridae, Viviparidae, Planorbidae, Ariophantidae, Neritidae and Corbiculidae. The Tarebia granifera of the Thiaridae family is the most common of 127, 92 and 47 in each station. There were Shannon-Wiener $(\mathrm{H}$ ') diversity index data where $\mathrm{H}^{\prime}$ each station was $1.3,1.5$ and 1.4 respectively. This data concludes that the water quality around the Kebon Kongok landfill is moderately polluted with moderate diversity criteria $\left(\mathrm{H}^{\prime}=1.0-2.0\right)$.

Key words: Kebon Kongok landfill, Indeks Shannon-Wienner, Mollusca, and Bioindicator.

Abstrak: Telah dilakukan penelitian di kawasan TPA Kebon Kongok dengan melihat keanekaragaman Mollusca sebagai bioindikator kualitas perairan. Penelitian ini penting dilakukan mengingat sungai di kawasan TPA Kebon Kongok dimanfaatkan oleh masyarakat sekitar untuk kebutuhan sehari-hari. Penelitian telah dilakukan pada bulan Mei-Juni 2018 di sungai Taman Ayu Kecamatan Gerung, Lombok Barat yang bertujuan untuk memberikan informasi mengenai kualitas perairan di kawasan tersebut. Penelitian dilakukan dengan metode purposive sampling menggunakan teknik jelajah. Ada 3 stasiun penelitian yang dipilih berdasarkan perbedaan kondisi lingkungan di sekitar perairan TPA Kebon Kongok. Stasiun 1 terletak di sebelah timur TPA Kebon Kongok yang bersampingan dengan kolam limbah lindi TPA, stasiun 2 terdapat di bagian barat laut TPA Kebon Kongok dimana letaknya berdekatan dengan badan sungai utama dan stasiun 3 terletak di sebelah barat daya yang berdampingan dengan pemukiman penduduk. Ditemukan 13 spesies Mollusca yang tergabung dalam 8 famili yakni Lymnaeidae, Ampullaroidae, Thiaridae, Viviparidae, Planorbidae, Ariophantidae, Neritidae dan Corbiculidae. Tarebia granifera dari famili Thiaridae merupakan individu terbanyak yakni 127, 92 dan 47 di masingmasing stasiun. Didapatkan data indeks keanekaragaman Shannon-Wiener $\left(\mathrm{H}^{\prime}\right)$ dimana $\mathrm{H}^{\prime}$ setiap stasiun berturut-turut yakni 1.3, 1.5 dan 1.4. Data ini 
menyimpulkan bahwa kualitas perairan sekitar TPA Kebon Kongok adalah tercemar sedang dengan kriteria diversitas sedang $\left(H^{\prime}=1,0-2,0\right)$.

Kata kunci: TPA Kebon Kongok, Indeks Shannon-Wienner, Mollusca, dan Bioindikator

\section{Pendahuluan}

Tempat Pembuangan Akhir (TPA) Kebon Kongok merupakan tempat pembuangan sampah akhir penduduk Kota Mataram dan Kabupaten Lombok Barat yang terletak di Desa Taman Ayu Kecamatan Gerung Kabupaten Lombok Barat. TPA Kebun Kongok menggunakan sistem penimbunan terkendali (sanitary landfill) yang memiliki luas sebesar 8,6 ha. Di sekitar TPA Kebun Kongok yaitu pada jarak $100 \mathrm{~m}$ terdapat aliran sungai yang dimanfaatkan oleh warga Desa Taman Ayu untuk kebutuhan sehari-hari seperti MCK (mandi, cuci dan kakus), irigasi, memancing, dsb. Aliran sungai tersebut diduga tercemar oleh limbah cair yang berasal dari TPA Kebon Kongok. Dugaan ini karena letak aliran sungai yang lebih rendah dari TPA dan juga pengelolaan sampah dengan sistem penimbunan yang sangat tidak terkelola dengan baik dapat menyebabkan tanah dan perairan sungai sekitar menjadi tercemar. Kondisi ini diperkuat oleh hasil penelitian Alfan (2017) terkait kondisi kesehatan masyarakat yang berada disekitar TPA kebun Kongok yang sebagian besar menderita penyakit seperti diare $61,6 \%$, penyakit kulit $47 \%$, cacingan $41,1 \%$, malaria $35,6 \%$ dan penyebab penyakit ISPA sebesar $31,5 \%$.

Penurunan kualitas perairan dapat dideteksi dengan berbagai analisis seperti, analisis fisika dan kimia air serta analisis biologi. Penggunaan analisis fisik dan kimia pada kondisi perairan lotik dengan sumber nutrisi yang dinamis seperti sungai kurang efektif karena nilainilai yang dihasilkan dapat menyimpang akibat perubahan yang terajadi. Penentuan kualitas air dengan menggunakan analisis biologi yaitu menggunakan organisme sebagai indikator dapat memberikan reaksi yang lebih baik untuk memantau kualitas perairan, karena keberadaan organime yang menetap dan terus terusan terpapar oleh bahan pencemar.Masukan buangan ke dalam sungai akan mengakibatkan terjadinya perubahan faktor fisika, kimia dan biologi di dalam perairan. Perubahan ini dapat mempengaruhi keberadaan bahan-bahan yang essensial dalam perairan sehingga dapat mengganggu lingkungan perairan dan biota perairan. Salah satu biota yang rentan terhadap perubahan lingkungan adalah moluska (Triatmojo, 1999)
Kelas mollusca merupakan salah satu contoh hewan benthos bertubuh lunak yang banyak hidup di perairan tawar. Gastropoda (keong bercangkang tunggal) dan Pelecypoda/Bivalvia (kerang bercangkang dua) merupakan jenis mollusca yang umum ditemukan di perairan tawar seperti sungai (Djajasasmita, 1999). Mollusca merupakan organisme hidup yang peka terhadap perubahan kualitas air tempat hidupnya sehingga hal ini dapat juga menentukan kepadatan dan keragaman populasi dari kelas tersebut (Odum, 1993). Penggunaan Keragaman mollusca (gastropoda dan bivalvia) sebagai bioindikator kualitas perairan telah dilakukan di kawasan pesisir Pulau Tunda Banten, hasilnya menunjukan kualitas perairan pesisir Pulau Tunda tercemar sangat ringan dengan kriteria indeks keanekaragaman yang tinggi Indria et al., (2017).

Berdasarkan hasil penelitian di atas pemanfaatan keanekaragam mollusca sebagai bioindiakator kualitas perairan sungai dapat dilakukan. Penelitian mengenai kualitas perairan sungai di sekitar TPA Kebon Kongok penting dilakukan mengingat keberadaan sungai sangat penting bagi masyarakat sekitar karena digunakan untuk kebutuhan sehari-hari. Hasil dari penelitian ini diharapkan dapat memberikan gambaran mengenai kualitas perairan sungai dalam upaya pengelolaan TPA Kebon Kongok yang berkelanjutan.

\section{Bahan dan Metode}

Alat yang digunakan dalam penelitian ini adalah saringan untuk mengambil sampel mollusca yang terdapat pada dasar sungai, thermometer, $\mathrm{pH}$ stick, kamera dan tabel pengamatan. Sedangkan bahan yang digunakan adalah alkohol $70 \%$ untuk mengawetkan sampel mollusca, kertas label, botol sampel dan kantung plastic (zip lock).

\section{Area kajian}

Pengambilan sampel dilakukan pada bulan MeiJuni 2018, yang betempat di Sungai sekitar tempat pembuangan akhir (TPA) Kebon Kongok Desa Taman Ayu Kecamatan Gerung Kabupaten Lombok Barat. 
Athifah et al, Jurnal Bologi Tropis, 19 (1) :54 - 60 DOI: $10.29303 /$ jbt.v19i1.774

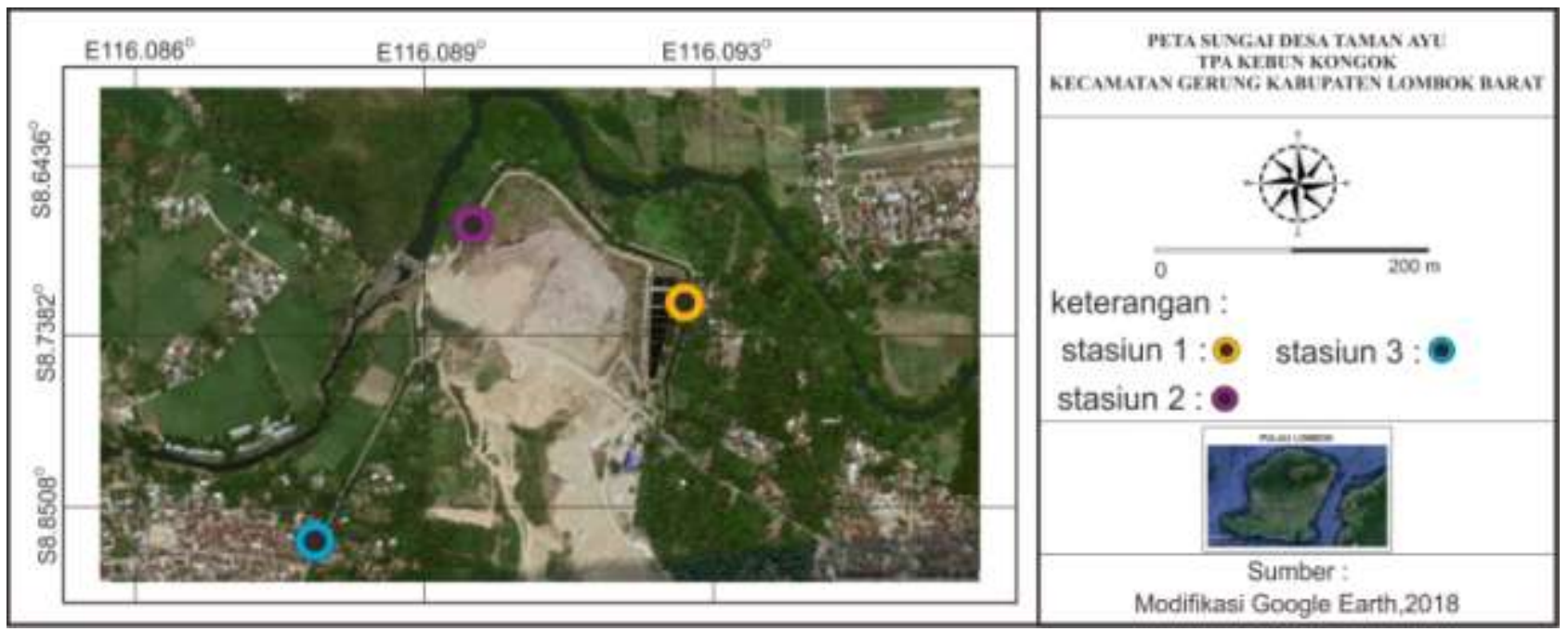

Gambar 1. Peta lokasi pegambilan sampel molusca di perairan sekitar TPA Kebon Kongok.

Gambaran Umum Kondisi Pada Setiap Stasiun

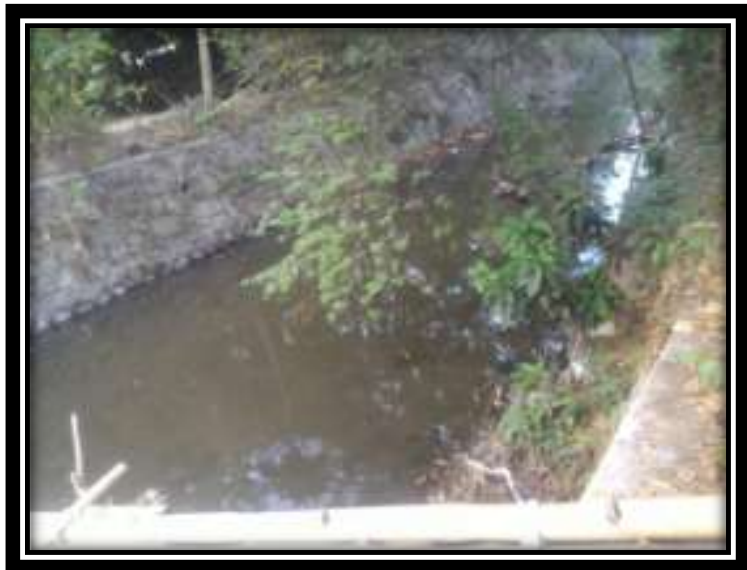

Gambar 2. Stasiun I

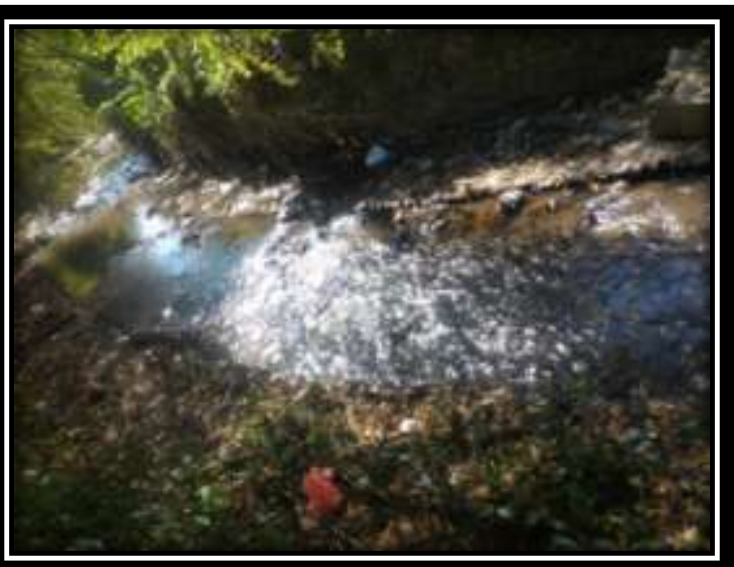

Gambar 3. stasiun II

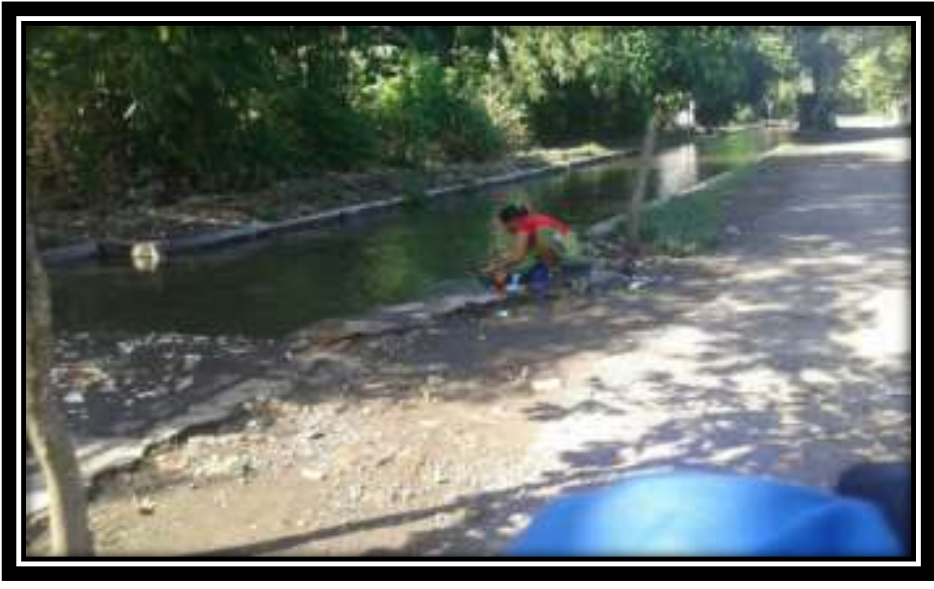

Gambar 4. Stasiun III 


\section{Cara kerja}

Penelitian ini menggunakan metode purposive sampling yaitu berdasarkan perbedaan kondisi lingkungan perairan sekitar TPA Kebon Kongok. Pengambilan data dilakukan dengan metode jelajah, yaitu dengan menyusuri seluruh stasiun yang telah di tentukan sepanjang lebak sungai di Desa Taman Ayu. Perairan sungai Desa Taman Ayu kami telah bagi menjadi tiga stasiun mulai aliran sungai di samping kolam pembuangan limbah lindi TPA Kebon Kongok, pertemuan sungai utama dan kawasan pemukiman masyarakat. Stasiun I terletak di sebelah timur TPA Kebon Kongok yang tepat bersampingan dengan kolam limbah lindi TPA tersebut, stasiun II terdapat di bagian barat laut TPA Kebon Kongok dimana letaknya berdekatan dengan badan sungai utama dan stasiun III terletak di sebelah barat dayayang juga berdampingan dengan pemukiman penduduk.

Pengambilan sampel Mollusca dilakukan dengan cara hand collecting (pemungutan) semua jenis Mollusca yang ditemukan. Mollusca yang ditemukan kemudian diidentifikasi menggunakan buku identifikasi "Keong dan Kerang Sawah LIPI Seri Panduan Lapangan" dan "Keong Dari Taman Nasional Gunung Halimun", sedangkan untuk Mollusca yang belum teridentifikasi diambil contoh dari tiap jenis Mollusca tersebut kemudian dimasukkan ke dalam botol sampel untuk diawetkan dengan alkohol $70 \%$ kemudian diidentifikasi di Laboratorium Biosistematika Hewan FMIPA Biologi Universitas Mataram. Sebagai data pendukung dari penelitian ini kami juga melakukan pengamatan terhadap jenis substrat dan vegetasi yang terdapat disetiap stasiun dan juga pengukuran faktor lingkungan berupa suhu dan $\mathrm{pH}$.

\section{Analisis data}

Analisis data yang digunakan untuk menghitung keanekaragaman spesies adalah rumus dari indeks keanekaragaman Shannon-Wiener (Odum, 1993) yaitu :

$$
\mathrm{H}^{\prime}=-\Sigma(\mathrm{Pi} \ln \mathrm{Pi})
$$

Keterangan :

$\mathrm{H}^{\prime}$ = indeks keanekaragaman spesies

$\mathrm{ni}=$ jumlah individu dari spesies ke-i

$\mathrm{Pi}=$ Kelimpahan relatif dari spesies ke-i....

$\mathrm{Pi}=(\mathrm{ni} / \mathrm{Nt})$

$\mathrm{Nt}=$ jumlah total individu dari semua jenis yang tercatat
Kriteria untuk indeks Shannon-Wiener:

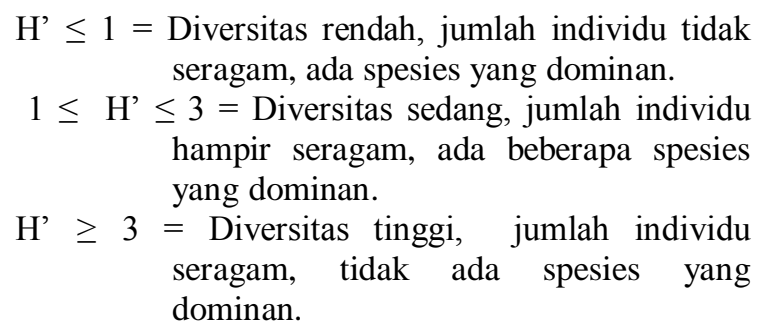

Untuk mengetahui kualitas perairan berdarkan indikator indeks keanekaragaman jenis Mollusca mengikuti kriteria Shanon-Winner, (Fachrul 2007) sebagai berikut:

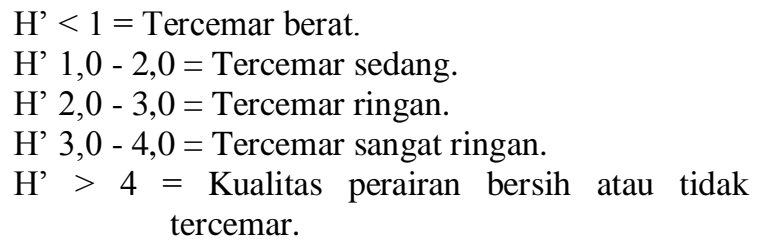

\section{Hasil dan Pembahasan}

\section{Jenis - Jenis Mollusca}

Hasil penelitian yang telah dilakukan mengenai keanekaragaman mollusca di sekitar TPA Kebun Kongok didapatkan 14 spesies mollusca yang tergolong dalam 8 famili yaitu Lymnaeidae, Ampullaroidae, Thiaridae, Viviparidae, Planorbidae, Ariophantidae, Neritidae dan Corbiculidae. Data keanekaragaman jenis Mollusca yang terdapat di sekitar perairan TPA Kebon Kongok dapat dilihat pada Tabel 1. 
Tabel 1. Jenis-Jenis Mollusca

\begin{tabular}{|c|c|c|c|c|}
\hline \multirow[t]{2}{*}{ No. } & \multirow[t]{2}{*}{ Family / Species } & \multicolumn{3}{|c|}{ Stasiun } \\
\hline & & I & II & III \\
\hline \multirow[t]{2}{*}{1.} & Lymnaeidae & & & \\
\hline & Lymnaea rubiginosa & 39 & 8 & 3 \\
\hline \multirow[t]{2}{*}{2.} & Ampullaroidae & & & \\
\hline & Pomacea caneliculata & 17 & 80 & 6 \\
\hline \multirow[t]{6}{*}{3.} & Thiaridae & & & \\
\hline & Tarebia granifera & 127 & 92 & 47 \\
\hline & Melanoides tuberculata & 11 & - & 2 \\
\hline & Melanoides granifera & 29 & - & 1 \\
\hline & Stenomelania sp. & - & 17 & - \\
\hline & Thiara scabra & - & - & 5 \\
\hline \multirow[t]{2}{*}{4.} & Viviparidae & & & \\
\hline & Bellamnya javanica & 2 & 33 & - \\
\hline \multirow[t]{2}{*}{5.} & Planorbidae & & & \\
\hline & Indroplanorbis exustus & 2 & 10 & 1 \\
\hline \multirow[t]{2}{*}{6.} & Ariophantidae & & & \\
\hline & Elaphroconcha javacencis & - & 1 & - \\
\hline \multirow[t]{2}{*}{7.} & Neritidae & & & \\
\hline & Neritina sp. & - & - & 4 \\
\hline \multirow[t]{3}{*}{8.} & Corbiculidae & & & \\
\hline & Corbicula sp. & - & - & 7 \\
\hline & Total & 227 & 241 & 76 \\
\hline
\end{tabular}

Berdasarkan Tabel 1 jumlah total individu Mollusca yang terdapat pada tiga stasiun berbeda di perairan kawasan TPA Kebon Kongok adalah 544 individu. Jumlah individu ini lebih tinggi dibanding hasil penelitian Nangin et al., (2015) di sungai Suhuyon Sulawesi Utara yaitu sebanyak 262 individu. Namun jumlah individu di kedua lokasi tersebut lebih rendah di bandingkan dengan hasil penelitian Indria et al., (2017) di pesisir Pulau Tunda Banten dengan jumlah total individu mollusca sebanyak 2.706 individu. Perbedaan panjang area samping dan jumlah sampling yang diambil diduga sebagai salah satu penyebab perbedaan jumlah tersebut. Dugaan lain perbedaan jumlah ini disebabkan karena kualitas perairan, substrat, vegetasi dan bahan pencemar yang ada di masing-masing lokasi tersebut.Keberadaan spesies Mollusca dipengaruhi oleh faktor fisika kimia perairan baik itu suhu, jenis vegetasi, $\mathrm{pH}$, nutrisi dan salah satunya substrat. Menurut Fajri dan Kasry (2013) substrat berupa lumpur merupakan subtrat yang banyak memiliki bahan kandungan organik. Gastropoda dan Bivalvia sangat menyukai habitat lumpur atau lumpur berpasir dalam bentuk berkumpul dan menyebar Indria et al (2017). Menurut Dittman (1990) pemangsaan atau kompetisi, lingkungan fisika kimia perairan yang kurang layak dapat menyebabkan perbedaan-perbedaan dalam kepadatan maupun jumlah jenis organisme.
Total individu Mollusca terbanyak ditemukan pada stasiun II yaitu sebesar 241 individu yang terdiri atas tujuh spesies yang tergabung dalam enam famili, dengan parameter lingkungan yang terukur yakni $\mathrm{pH} 6$ dengan suhu $28^{\circ} \mathrm{C}$. Banyaknya individu yang ditemukan pada stasiun II diduga karena pada stasiun tersebut merupakan daerah peralihan dan pertemuan beberapa aliran air baik alran air yang sudah mulai kelihatan tercemar dengan aliran air yang terlihat masih bersih bersih. Kondisi ini dimungkinkan karena lokasinya yang berdekatan dengan sungai utama dan juga bendungan yang ada didaerah tersebut.

Pada stasiun I total individu yang ditemukan 227 individu, yang terdiri dari tujuh spesies yang tergabung dalam lima famili. Tingginya total individu yang ditemukan pada stasiun I diduga karena adanya dominasi satu spesies yang jumlah individunya sangat banyak yaitu $T$. granifera. Tingginya jumlah $T$. granifera yang ditemukan diduga berhubungan dengan substrat dimana mereka hidup dan mencari makan dan juga daya toleransi mereka terhadap lingkungan yang ekstrim. Menurut Syaifudin et al., (2017) Tarebia granifera merupakan jenis Mollusca yang tersebar luas di wilyah Indonesia dan dijumpai setiap hari di area persawahan dan sungai.

Total jumlah individu paling sedikit ditemukan yaitu di stasiun III dengan jumlah individu sebanyak 76 individu yang terdiri atas sembilan spesies dan tergabung 
dalam enam famili. Kondisi ini diduga karena tidak ada jenis Mollusca yang mendominasi, sertaditemukan beberapa jenis mollusca yang diambil oleh penduduk setempat untuk dikonsumsi.

Lymnaea rubiginosa, Pomacea caneliculata, Tarebia granifera, dan Indroplanorbis exustus merupakan spesies yang ditemukan hampir disemua stasiun penelitian. Hal ini menunjukan bahwa spesies tersebut memiliki kemampuan adaptasi yang tinggi baik di substrat yang lunak (lumpur) maupun yang keras. Dilihat dari daya tolensi terhadap bahan pencemar. Kelompok spesies ini diduga termasuk dalam kelompok jenis fakultatif yaitu dapat bertahan hidup terhadap lingkungan yang agak lebar, antara perairan yang belum tercemar sampai dengan tercemar sedang dan masih dapat hidup pada perairan yang tercemar berat.

Bellamnya javanica merupakan spesies yang ditemukan di stasiun I dan II kondisi ini diduga karena keberadaan substrat pada kedua stasiun tersebut yaitu sama-sama berlumpur. Menurut Sriwahyono (2005) Bellamnya javanica merupakan siput yang banyak ditemukan didasar yang berlumpur dan mampu berkembang dengan baik di habitat sawah. Melanoides tuberculata dan Melanoides granifera. Merupakan spesies yang hanya ditemukan stasiun I dan III. Hal ini disebabkan karena tingkat toleransi hidup spesies Melanoides sp. terhadap bahan pencemar lebih tinggi dibanding spesies lainnya. Sesuai dengan penelitian Fisesa et al., (2014) yang menyatakan bahwa Melanoides sp. merupakan spesies indikator yang hidup di perairan yang banyak mengandung bahan organik, juga mampu hidup pada kondisi oksigen terlarut (DO) rendah dengan partikel tersuspensi yang tinggi.

Pada stasiun II ditemukan jenis Stenomelania sp dan Elaphroconcha javacencis, kedua jenis Mollusca ini hanya ditemukan pada stasiun II. Diduga hal ini disebabkan karena adanya perpindahan habitat kedua jenis Mollusca ini dari perairan bersih yang berasal dari sungai utama atau bendungan menuju anak sungai tempat pengambilan sampel. Terdapat 3 spesies mollusca yang hanya ditemukan di stasiun III yakni Thiara scabra, Neritina sp. dan Corbicula sp. Hal ini disebabkan karena substrat pada stasiun III merupakan substrat paling cocok untuk kehidupan mollusca jenis ini yakni lumpur berpasir, selain itu juga terdapat vegetasi bambu yang menyebabkan hadirnya tiga spesies ini.

\section{Indeks Keanekaragaman Mollusca}

Berdasarkan hasil penelitian yang dilakukan di aliran sungai sekitar TPA Kebun Kongok di peroleh indeks keanekaragaman dapat dilihat pada Tabel 2.
Tabel 2. Indeks Keanekaragaman (H')

\begin{tabular}{ll}
\hline Lokasi & H' \\
\hline Stasiun I & 1.3 \\
Stasiun II & 1.5 \\
Stasiun III & 1.4 \\
\hline
\end{tabular}

Indeks Keanekaragaman (H') di aliran sungai sekitar TPA Kebon Kongok berkisar antara 1,3 1,5.Indeks keanekaragaman tertinggi sebesar 1.5 terdapat di stasiun II dan terendah di stasiun I sebesar 1.3 (Tabel. 2). Berdasarkan indek keanekaragam Shannon Winer secara keseluruhan keanekaragaman Molusca di perairan TPA kebun kongok tergolong sedang. Kondisi ini menggambarkan bahwa jumlah individu hampir seragam dan ada beberapa jenis spesies yang mendominasi. Menurut Mustofa et al (2014) adanya dominansi suatu organisme menandakan bahwa tidak semua organisme memiliki daya adaptasi dan kemampuan bertahan hidup yang sama di suatu tempat.

Berdasarkan indek keanekaragam Shannon Winer secara keseluruhan kualitas perairan di aliran sungai TPA kebun kongok berada dalam kondisi tercemar sedang.Tingkat keanekaragaman organisme yang terdapat di lingkungan perairan tertentu merupakan cerminan variasi daripada toleransinya terhadap kisarankisaran parameter lingkungan.Suatu perairan yang belum tercemar akan menunjukkan jumlah individu yang seimbang dan hampir semua spesies ada. Sebaliknya suatu perairan yang tercemar, penyebaran jumlah individu tidak merata dan cenderung ada spesies yang mendominasi. Kondisi ini terlihat adanya dominansi spesies yang menyebabkan rendahnya nilai indeks keanekaragaman pada stastiun I

\section{Kesimpulan}

Berdasarkan hasil penelitian mengenai keanekaragaman mollusca sebagai bioindikator kualitas perairan didapatkan 14 spesies mollusca yang tergabung dalam 8 famili. Tarebia granifera memiliki jumlah individu tertinggi. Jenis ini merupakan kelompok organisme toleran mempunyai daya toleran yang lebar, sehingga dapat berkembang mencapai kepadatan tertinggi dalam perairan yang tercemar berat. Dan potensial sebagai bioindikator.

\section{Ucapan Terima Kasih}

Penulis mengucapkan terima kasih kepada Dr. Immy Suci Rohyani dan Dr. Yuliadi Zamroni atas bimbingan, bantuan literatur, serta peminjaman buku 
identifikasi. Begitupula ucapan terima kasih untuk Rosalina Edy, M.Si atas saran perbaikan, masukan koreksinya selama proses pembuatan tulisan ini. Terima kasih juga disampaikan kepada para teknisi Laboratorium Biologi Universitas Mataram dan tenaga lapangan yang telah membantu dalam proses peneyelesaian laporan dan penelitian.

\section{Daftar Pustaka}

Alfan, M. (2017). Dampak Tempat Pembuangn Akhir (TPA) Sampah Kebon Kongok Terhadap Gangguan Kesehatan Masyarakat Desa Suka Makmur Kecamatan Gerung Kabupaten Lombok Barat. Skripsi : UIN Mataram.

Dittman, S. (1990). Mussel Beds-Amensalism or Amelioration For Interdal Fauna. Helgolander Meeresunters. 44 : 335-352.

Djajasasmita, M. (1999). Keong dan Karang Sawah Seri Panduan Lapangan. Puslitbang Biologi LIPI : Cibinong.

Fachrul, M. F. (2007). Metode Sampling Bioekologi. Jakarta: Universitas Indonesia Press.

Fajri, E.N. \& Kasry, A. (2013). Kualitas Perairan Muara Sungai Siak Ditinjau Dari Sifat Fisika Kimia dan Makrozoobentos. Berkala Perikanan Terubuk. 41(1): 37-52.

Fisesa, E. D., Isdradjad, S. \& Majariana, K. (2014). Kondisi Perairan dan Struktur Komunitas Makrozoobentos di Sungai Belumai Kabupaten Deli Serdang Provinsi Sumatera Utara. Depik. 3(1): $1-9$.

Indria, W., Indah, J. W., \& Bambang, E. (2017). Biodiversitas Mollusca (Gastropoda dan Bivalvia) Sebagai Bioindikator Kualitas Perairan di Kawasan Pesisir Pulau Tunda, Banten. Biodidaktika. 12(2) : 45-56.

Mushtofa, A., Rudiyanti, S. \& Rudolf, M. M. (2014). Analisis struktur komunitas makrozoobenthos sebagai bioindikator kualitas perairan sungai wedung kabupaten Demak. Diponogoro Journal of Maquares. (online) vol 3 nol.

Nangin, S. R., Marnix L.L., \& Deidy Y. K. (2015). Makrozoobentos Sebagai Indikator Biologis dalam Menentukan Kualitas Air Sungai Suhuyon Sulawesi Utara. Jurnal MIPA UNSRAT. 4(2) : 165-168.
Odum, E.P. (1993). Dasar-dasar Ekologi. Terjemahan Tjahjono Samingan. Edisi. Ketiga. Yogyakarta: Gadjah Mada University Press.

Sriwahyono. (2005). Identifikasi Populasi Gastropoda Air Tawar di Waduk Saguling dan Sekitarnya. JurnalTeknik Lingkungan. 6(1) : 274-282.

Syaifudin, Z. A., Sri U., \& Joko W. (2017). Keanekaragaman dan Kemelimpahan Mollusca pada Area Persawahan Desa Sekarputih Sebagai Modul Pembelajaran Hewan Invertebrata SMA Kelas X. Prosiding Seminar Nasional SIMBIOSIS II. 501-508.

Triatmojo, B. (1999). Teknik Pantai. Beta Offset. Yogyakarta. $379 \mathrm{hlm}$ 